\title{
Content analysis of the sixth-grade book of "thought and research" based on curriculum criteria (Philosophy for Children)
}

\author{
Fatemeh Yakhchalian, Naser Seraj Khorrami* \\ Department of Educational Sciences - Training Planning, Dezful Branch, \\ Islamic Azad university, Dezful, Iran \\ *E-mail address: Dr_sarraj@yahoo.com
}

\begin{abstract}
This study aims to achieve a level of training categories (Philosophy for Children) on the content of thought and research sixth-grade book published in 2013. Studies were carried out according to the method of application and descriptive data collection, in which data was collected by content analysis method. Data collection tools in the study are checklists of teaching philosophy to children program criteria, including four concepts (reasoning, conceptualization, judgment and wisdom) and sixteen sub-components. In this study, analysis basis was sentences, paragraphs and questions on the content of the studied book. Due to the limited size of the population, the 'sample population' was selected. The descriptive analysis methods (frequency, percentage and mean tables) were used for analyzing the findings. The results showed that the authors have paid more attention to some components of teaching philosophy to children, such as links between concepts, reality representation, cognition, inductive and deductive methods, application of criteria, difference, similarity, and decentralization and less attention to some components such as benchmarking, consistent beliefs and behaviors, true-heartedness and good deeds, faith to good words and deeds, and knowing the truth.
\end{abstract}

Keywords: content analysis; thought and research; sixth grade; teaching philosophy to children

\section{INTRODUCTION}

Now that we've taken a step forward in a rapidly changing era, so it seems that our power and influence factors for this instability are intellectual capabilities and skills. That is, let us teach people to boost their thinking about the life events in order to establish active and creative associations between themselves and surrounding phenomena, so one of the fundamental characteristics of human is to have knowledge of their behaviors and to possess the power of thinking.

About 45 years ago in 1969 at Columbia University, Lipman et al(1980), who later became president of development Institute of Philosophy for Children program at Montclair state college, New Jersey, suggested this theory that if we engage a child's mind in philosophical discussions, we could develop their thinking. Lipman et al (1980) argued that if we can associate the natural curiosity of children and their tendency to know about the world 
with the philosophy, we could make those children become thinkers who are more critics, flexible and effective than ever (Barrow, 2010).

Offering many exercises to learners, the program tries to train children so as they could find good rational reasons, and thereby extend their horizons for surrounding issues. It teaches them how to think; of course, to achieve this goal, both experienced teachers and appropriate teaching techniques are required. This is why Lipman et al (1980) for designing philosophy for children, developed philosophical fiction books as well as teacher guide books. However, what is important here and Lipman et al (1980), also emphasized on is to naturalize issues and consider the climatic, cultural and social conditions that the better results would obtain if they are followed. To do so, program implementation in any country requires that those involved in the education provide the necessary contexts for performing the program (Marashi, 2008). Intellectual skills are not a blessing for certain people. It is not innate, inherited trait, as by using proper practices, these skills could be developed in children (Lipman et al, 1980). The results of some investigation on textbooks indicate that intellectual skills received less interest in the textbooks (Salehi Omran \& Chaharbashlu, 2010). Naji (2009) argues that in our country, due to the dominance of Piaget's spirit upon the education system, it seems that the new changes in textbooks and other matters related to teaching is unaware of the revolution the philosophy of children has emerged in the world. Therefore, the necessity for regarding intellectual skills in education is inevitable.

Among the main constituents of the educational system, curriculum, teaching environment, and teacher are noteworthy. These three bases are totally strengthening or weakening factors of intellectual skills in students (Hosseini, 2004). Today in most educational systems, textbook is the main educational tool, and teachers and students rely on book in teaching-learning activities (Maleki, 2007). The more productive content of textbooks to provide a suitable basis for developing the thinking is, on the one hand, the more it helps creating mighty, regenerator, and innovative men, and on the other hand, the more effective it helps to maintain the independence, growth and prosperity in the community.

In the early elementary school textbook surveys, researchers found that the thought and research book has used story more than other books to convey the concepts. While in thought and research curriculum title in the sixth grade, the two words of "thought" and "research" is used, but due to the nature of the program, it is not two topics with two different concepts and functions. This program seeks to foster thinking and reasoning that are innate in children. The program is about to put students in thinking path that is consistent with the definition of thinking in religious principles (Daneshvar et al, 2011).

What seems important is that, according to several books taught in the primary schools and different philosophical thinking skills as required by Lipman et al (1980), a comprehensive analysis has not been done so far in this case of elementary textbooks. Hence, the present study attempts to examine the content of thought and research book of the sixth grade, which representing one of the elements of the education system can play a significant role in the development of intellectual skills, and discover the advantages the book taken from the components of teaching philosophy to children. With regard to the research subject, studies carried out in both fields of philosophy for children and analysis of the content of textbooks were explored that in a number of which is referred afterwards.

Javidi Kalateh Jafarabadi and Akbari (2009) examined the criteria for providing reading and fictional materials appropriate for performing P4C curriculum. Some of these measures include the provision of books and materials in a fictional manner, involving philosophical themes and points in the triple realms of metaphysics, epistemology and particularly axiology, and finally, considering the child's age and their psychological capabilities, limitations and 
needs in the preparation of these materials. He believes that these books can be formulated in such a way that the philosophical qualities, without apparent representation are addressed in the whole story. In this way, through the group study of story and discussion about it, the children are able to discover points of interest, which in turn allows for the institutionalization of these qualities in the character of children and adolescents.

Farzanfar (2010) concluded in a research that two approaches are generally governing this period. The first approach, which has cast shadows on most periods, insists on unawareness, autism, weakness and tendency of children to inferior instincts. This approach could be called "child like a tool". In contrast, the second approach emphasizes on child's awareness, spirit of inquiry, creativity, innocence and imagination. "The child as a target" is the name that could be put on this approach. Any discussion of the philosophy of childhood, whether in literary or educational perspective, is consistent with one of the two approaches.

Marashi (2006) investigated the impact of the program on reasoning skills of female and male junior high school students and positive results were obtained.

In 2011, Marashi, Hashemi and Moghimi Gasak concluded in a research that in the examined textbooks, the subject of reasoning had the highest rate of frequency and attention to the judgment was the lowest. Also in the studied textbooks, 'Let's read and write' book was addressed the subject of philosophical thought more than 'Divine gifts'.

In a survey by Tricky (2006), it was shown that teaching philosophy made a significant change in the children's verbal and nonverbal reasoning and teachers doubly used open-ended questions, the children improved considerably listening and speaking, asking, reasoning, reading and writing, understanding and behaving, and their talking time during 5 class hours increased from 41 to 66 percent and about 6.5 score was added to children's IQ.

In Jessica's study (2007), the results showed significant differences between two implementations that caused strategies, providing deeper and more comprehensive understanding of scientific content to be better understood.

Hanna (2007) in an article entitled 'Child, philosophy and teaching: A discussion about intelligent resources' studied the theoretical basis of philosophy for children program based on the plan of Lipman et al. The purpose of this article at first is setting fundamental philosophical and educational principles for $\mathrm{P} 4 \mathrm{C}$ according to American pragmatism and complementary issues in Lipman thought and the second aim of this study was specifically the thoughts of John Dewey, George H. Mead and Vygotsky. Lipman et al (1980) knows the works of these people the most basic resources for their thoughts.

Barrow (2010) in a survey states that the dialogue as a tool for participation can have a significant impact in improving the reading ability of children and the interaction with others. The dialogue practice is also able to enhance the tolerance of participants. Therefore, this practice in philosophy for children program can be applied in many school curricula and reduce the problems resulting from different inequality between the participants in the research community and increase their self-confidence.

Albergaria (2011) in an article suggests that in order to improve reading and writing skills, one can strengthen intelligence with a set of cognitive skills such as critical thinking, creativity, and questioning skills. 


\section{METHODOLOGY}

The content analysis in this research was a quantitative one. The population was the sixth-grade book of thought and research, published in 2013, which is a total of 30 lessons. Due to the limited size of the population (a book), there is no need to sampling and all the information in this book as a population (sample equals population) were selected and analyzed. The data collection tool in this study, which was conducted by the method of content analysis, is "a system of categorization and coding variables" that can be referred to as a "checklist". Thus, the first component of teaching philosophy to children, which includes 16 components of teaching philosophy to children in 4 criteria that the following criteria and their components are also used in other studies (Parirokh et al, 2010) that are identified according to the characteristics and relevant literature. Therefore, 4 criteria, including conceptualization, reasoning, judgment and wisdom have to be examined.

\section{Reliability and validity indices}

This tool was evaluated and scored in a preliminary study with 10 teachers and 2 educational experts to analyze the desired content in terms of reliability and validity. According to the agreement rate between judges for the whole questionnaire, validity index was calculated to be 0.85 . To calculate the reliability of the above tool, a sample of the content of thought and research book on two consecutive occasions with an interval of one week was coded by two coders. Then, it was calculated between two occasions and the index of 0.93 was obtained from criteria check list of philosophy for children's program. The correlation showed high reliability that was acceptable and needed to ensure measuring tools.

\section{Data analysis method}

To analyze the data from the content analysis form, descriptive statistics (frequency, percentage and average tables) were used.

\section{FINDINGS}

In this section, tables related to frequency in sixth-grade book of thought and research has been shown.

Table 1. Frequency distribution of philosophical thinking criteria in sixth-grade book of thought and research.

\begin{tabular}{|c|c|c|}
\hline Criteria of teaching philosophy & Frequency & Percent \\
\hline Conceptualization & 52 & 25 \\
\hline Reasoning & 58 & 29 \\
\hline Judgment & 74 & 36 \\
\hline Wisdom & 20 & 100 \\
\hline Total & 204 & 10 \\
\hline
\end{tabular}


Table 2. Frequency distribution of philosophical thinking concepts and components in sixth-grade book of thought and research.

\begin{tabular}{|c|c|c|c|}
\hline Component & Index & Frequency & Percent \\
\hline \multirow{3}{*}{ Conceptualization } & Links between concepts & 12 & 23 \\
\cline { 2 - 4 } & Reality representation & 18 & 35 \\
\cline { 2 - 4 } & Benchmarking & 7 & 13 \\
\hline \multirow{3}{*}{ Reasoning } & Cognition & 15 & 29 \\
\cline { 2 - 4 } & Inductive & 19 & 33 \\
\hline \multirow{3}{*}{ Judgment } & Deductive & 18 & 67 \\
\cline { 2 - 4 } & Application of criteria & 26 & 35 \\
\cline { 2 - 4 } & Difference and similarity & 30 & 41 \\
\hline \multirow{3}{*}{ Wisdom } & Decentralization & 7 & 35 \\
\cline { 2 - 4 } & Consistent beliefs and behaviors & 3 & 15 \\
\cline { 2 - 4 } & True-heartedness and good deeds & 4 & 20 \\
\cline { 2 - 4 } & Faith to good words and deeds & 6 & 30 \\
\cline { 2 - 4 } & Knowing the truth & & 24 \\
\hline
\end{tabular}

As indicated in table 1, the maximum frequency percent among the teaching philosophy criteria is for judgment criterion (36\%) and lowest frequency is for wisdom criterion $(10 \%)$. As is clear from table 2, the highest frequency percent among the component criteria of teaching philosophy conceptualization relates to the component of reality representation $(35 \%)$ and the lowest frequency percent relates to the component of benchmarking $(13 \%)$. The highest frequency percent among the component criteria of teaching philosophy reasoning relates to the deductive component $(67 \%)$ and the lowest frequency percent relates to the inductive component $(33 \%)$. The highest frequency percent among the component criteria of teaching philosophy judgment relates to the decentralization component (41\%) and the lowest frequency percent relates to the component of application of the criteria (24\%). The highest frequency percent among the component criteria of teaching philosophy wisdom relates to the component of consistent beliefs and behaviors $(43 \%)$ and the lowest frequency percent relates to the component of true-heartedness and good deeds $(15 \%)$.

\section{DISCUSSION}

The results in table 1 revealed that the highest frequency percent among the teaching philosophy criteria relates to the judgment criterion of $36 \%$ and 74 frequencies which indicates that it is addressed quite well in the book and lowest frequency percent belongs to wisdom by $10 \%$ and 20 frequencies, which has neglected. Results obtained from this 
research's main question are consistent with researches conducted by Parirokh et al (2010), Tricky (2006) regarding the reasoning criteria, and Naji (2009).

Since thought development in grades before the sixth grade has not been pursued based on a formulated curriculum, this program in the sixth grade considered transitional that in one hand, is built according to the realized goals and thinking skills and types in previous curriculum of five grades, and on the other hand, is looking for filling the existing gaps and links between these sub-skills and reach a higher level of thinking and research competency, and with respect to the objectives of the curriculum in this book looking for fostering thought and intellect that there are innate in children; thinking defined in religious principles is beyond the existing classifications. This program seeks to put students in the way of thinking that is compatible with the definition of religious medical thinking. Thought and research are not just in the sense of material phenomena and experimental research, but also encompass the human and social phenomena and religious issues. Therefore, the results of this study showed that curriculum planners and textbook authors in the sixth-grade book of thought and research in the field of components of wisdom criterion dealing with skills such as knowledge about facts (being's) and the best attitude to achieve happiness and perfection (do's and don'ts), understanding and attaining the truth by thinking, or in other words, by thinking and intellect skills (knowing the facts) that these facts can be divided into two categories: the first category of fact is realities and creatures of the universe and the rules governing them and the relations between them. God, angels, stars, galaxies, earth, trees, animals, humans and the rules and relations between them are examples of these facts. Another set of facts relates to human actions and behaviors, namely the goodness and values that every human should adhere to it: truthfulness, seeking justice, respect for the rights of others, respect for parents, doing essentials, avoiding taboos, respect for the law and etc. have performed very weakly.

Thus, it is proposed that in order to resolve these defects, the authors and curriculum planners should allocate more stories on the theme of wisdom and its components in the book and dear teachers strengthen and develop further teaching philosophy skills to students with open-mindedness and full knowledge and study for the mentioned skills.

\section{CONCLUSIONS}

Based on the discussions it can be concluded that in order for developing philosophical thinking in children and adolescents, it is essential that they have a unity of thought, deep understanding and intellectual flexibility. These features would develop thinking in the child and adolescent if they can achieve mastery of reasoning, conceptualization and judgment methods, thus forming critical thinking skills in them and helping them contemplate in a philosophical way. These people are allowed to decide and choose in their life and can live freely. In general, allocating this textbook to other ones is very well-thought and appropriate and with the addition of only a few stories rich in educational topics of philosophical thinking for the children, this book is can be full and perfect. Due to the fact that the main objective of present research is to study the contents of the sixth-grade elementary book thought and research, it is suggested that:

1. Launching in-service training courses and workshops, meetings, scientific committees and communities active in the teachers' level, the necessity to use the teaching philosophy criteria be trained.

2. Due to the low quantity of the stories related to the wisdom criterion, it is recommended that this criterion receives more interest by inviting experts and researchers and 
collaborating research institutions with the education system and more stories related to the criterion of wisdom added to the sixth-grade elementary book thought and research.

3. Due to the high volume of books, such as math, science, etc., and not enough time to deal with the concepts of thought and research book, it is proposed that several teachers to be dedicated to this grade, so that each teacher could train in the area of interest as much better as they can.

4. It is suggested that some researches are carried out regarding the use of textbook planners and authors of textbook content analysis research done by others, in order to solve the problems of textbooks.

\section{References}

[1] Parirokh, M., Parirokh, Z., \& Majdi, Z. (2010). The trace of philosophical concepts in children's stories, research on the identification of factors associated with the education of philosophical thought. Studies in Librarianship and Information Science, 16(4): $57-$ 80 .

[2] Javidi Kalateh Jafarabadi, T., \& Akbari, A. (2009). "Analysis of the P4C curriculum and appropriate reading material features for its implementation", National Conference on School Libraries, activating education system and participation in the teachinglearning process, Mashhad.

[3] Hosseini, A. (2004). The nature of creativity and its enhancing practices. Mashhad: Astan Quds Razavi publication.

[4] Daneshvar, M., Gholam Hossein, A., Spidkar, M., Roshandel, Ali Akbar., Hamzeh Beigi, T., \& Saffari Nazari, M. (2011). The teacher book of sixth-grade thought and research. Tehran: University of Tehran Publication.

[5] Salehi Omran, A., \& Chaharbashlu, H. (2010). "Content analysis of the textbooks of primary education schools based on the components of creativity as one way of enhancing creativity in students", The Third National Conference of Understanding Creativity (TRIZ) and innovation engineering and management, Tehran, IRAN.

[6] Farzanfar, J. (2010). "Studying philosophy of childhood and the role of story in the development of philosophical spirit in children", $\mathrm{PhD}$ thesis in Philosophy of Education, Teacher Training University, Tehran.

[7] Marashi, M. (2008). "Teaching philosophy to children, a new approach to the curriculum", the education, On the occasion of celebrating Pakseresht, MJ, Shahid Chamran University, Ahwaz.

[8] Marashi, M. (2006) "investigating the effect of Research community method in teaching philosophy to children's program on the reasoning skills of third-grade male junior high school students", doctoral dissertation, Faculty of Education and Psychology, Shahid Chamran University, Ahwaz.

[9] Maleki, H. (2007). Curriculum planning guideline. Mashhad: Payam Andisheh publication.

[10] Naji, S. (2009). "The new interpretation of Islamic Education (recovering the components of the philosophy for children program)". Farhang, 69: 177-214. 
[11] Albergaria, P. (2011). Critical Thinking, Questioning and Creativity as Components of Inteligence. Journal of Procedia-Social and Behavioral Sciences, 30: 80-91.

[12] Barrow, W. (2010). Dialogic, Participation, and the Potential for Philosophy for Hagman, Sally, (1990A), "Philosophical Aesthetics in Art Education: A further look toward implementation”, in Art Education, V.43, No.4 Children's Thinking Skills and Creativity, Vol. 5, NO. 2.

[13] Hanna, J. (2007). Child, Philosophy and Education, Discussing the Intellectual Sources of Philosophy for Children, Finland: Oulu University.

[14] Jessica, G (2007). Companying classroom of an inquiry curriculum, Lawrence Erlbaum associates.

[15] Lipman, M., A. M. Sharp, and P. Oscanian (1980). Philosophy in the Classroom, Philadelphia: Temple University.

[16] Tricky. S (2006). "Effects of P4C in 100 primary schools" Educational research, Spring 2006, No.1. 